\title{
Induction of apoptosis and change of bcl-2 expression in macrophage Ana-1 cells by all-trans retinoic acid
}

Yin De Ling, Xiu Hai Ren, Shi Zhong BU, Ya Lan WU, Li Zhen JiAnG, Zhi Jiang Wu, Wei HU, Gang $\mathrm{PEI}^{1}$

Shanghai Institute of Cell Biology, Chinese Academy of Sciences, Shanghai 200031, China.

\begin{abstract}
Macrophage cells play an important role in the initiation and regulation of the immune response. All-trans retinoic acid (ATRA) and its natural and synthetic analogs (retinoids) affect a large number of biological processes. Recently, retinoids have been shown promise in the therapy and prevention of various cancers. However, many interesting questions related to the activities of retinoids remain to be answered: (I) Molecular mechanisms by which retinoids exert their effects; (II) why the clinical uses of retinoids give undesirable side effects of varying severity with a higher frequency of blood system symptoms; (III) little is known for its impacts on macrophage cells etc. We set up this experiment, therefore, to examine the apoptosis of ATRA on macrophage Ana-1 cell line. Apoptosis of the cells was quantitated, after staining cells with propidium iodide (PI), by both accounting nuclear condensation and flow cytometry. When the cells were treated with ATRA at or higher than $1 \mu M$ for more than $24 \mathrm{~h}$, significant amount of the apoptotic cells was observed. Induction of apoptosis of Ana-1 cells by ATRA was in time- and dose-dependent manners, exhibiting the similar pattern as the apoptosis induced by actinomycin D (ACTD). ATRA treatment of Ana-1 cells also caused the changes of the mRNA levels of
\end{abstract}

1. Correspondence: Dr. G. Pei, Shanghai Institute of Cell Biology, Chinese Academy of Sciences, 320 Yue Yang Road, Shanghai 200031, China

Abbreviations: all-trans retinoic acid (ATRA); propidium iodide (PI); actinomycin D (ACTD); phosphate buffered saline (PBS). 
apoptosis-associated gene bcl-2, as detected by Northern blot analysis. The temporal changes of bcl-2 expression by ATRA was also parallel to that by ACTD. In conclusion, ATRA can induce apoptosis in macrophage cells, which may be helpful in understanding of immunological functions retinoids.

Key words: All-trans retinoic acid, apoptosis, Ana-1 cells, bcl-2.

\section{INTRODUCTION}

Retinoids possess a broad spectrum of biological activities relevant to various aspects of growth, differentiation, morphogenesis and development, and immune response[1]. In clinical aspects, retinoids have been tested extensively in cancer therapy and prevention[2,3]. The most successful case so far has been to use all-trans retinoic acid (ATRA) in treatment of patients with acute promyelocytic leukemia[47]. However, the molecular mechanisms underlying the effects of retinoids are not fully understood yet.

Many therapeutic reagents have been reported to exert their anti-cancer effects through induction of cell apoptosis, the programmed cell death[8-12]. Recent studies have also shown that retinoids can induce apoptosis in some cancer cells[3, 6], as well as human B lymphocytes[5]. Induction of cell apoptosis by retinoids is considered to be related to change of expression of bcl-2 gene, an important regulator in apoptosis[6]. There is no report yet in the aspect of its apoptotic effect on macrophage cells, which plays crucial immunological functions. In this report, we demonstrated, using Ana-1 cells as a model system, ATRA indeed induced apoptosis of macrophage in time- and dose-dependent manners. Treatment of Ana-1 cells with ATRA were also associated with the change in the expression of apoptosis-associated gene bcl-2.

\section{MATERIALS AND METHODS}

\section{Cell cultures and drug treatment}

Macrophage Ana-1 cells were kindly provided by professor Z. L. Zhang, and grown in RPMI 1640 (GIBCO) supplemented with 10\% heat-inactivated fetal calf serum (Evergreen), $100 \mathrm{U} / \mathrm{ml}$ penicillin, $100 \mu \mathrm{g} / \mathrm{ml}$ streptomycin and $2 \mathrm{~m} M$ glutamine. Exponentially growing Ana- 1 cells $\left(5 \times 10^{4}\right.$ cells $/ \mathrm{ml}$ ) were treated with different concentrations, as indicated in the figures, of ATRA (Sigma) or actinomycin D (ACTD, Sigma) for 12, 24, 48, or $72 \mathrm{~h}$.

\section{Morphological analysis of apoptotic cells}

Random fields of each treated cultures were photographed through a $40 \times$ objective lens in both the phase and the fluorescent modes. Apoptotic cells, after staining with propidium iodide (PI, Sigma), were much smaller than the viable cells and presented a condensed chromatin and fragmented nuclear chromatin bodies[13-15]. The percentage of apoptotic cells was calculated by 
counting at least 500 cells. Independent experiments were carried out for at least three times, and the data were given as the mean \pm SEM.

\section{Apoptotic analysis by flow cytometry}

ATRA-treated and untreated Ana- 1 cells $2 \times 10^{6}$ were washed twice with phosphate buffered saline (PBS) containing $0.1 \%$ glucose and then fixed in $1 \mathrm{ml}$ ice-cold ethanol overnight at $4^{\circ} \mathrm{C}$. The fixed cells were pelleted and resuspended in $0.5 \mathrm{ml}$ of PBS containing $0.1 \%$ glucose, $30 \mu \mathrm{g} / \mathrm{ml}$ PI, and $1 \mathrm{mg} / \mathrm{ml}$ RNase A (Sigma). The DNA contents of the cell were analyzed by flow cytometry (Becton-Dickinson, San Jose. CA) as described[16, 17].

\section{Northern blot analysis}

Extraction of total RNA and Northern blots were performed as described[18]. Blots were then hybridized to a DNA probe of human bcl-2 gene with the EcoRI/Hind III insert from plasmid PFL1[19], which was radiolabeled with $\alpha_{-}{ }_{-}^{32}$ p-dATP (Amersham) using random primering to a specific activity of 1-2 $\times 10^{9} \mathrm{cpm} / \mu \mathrm{g}$ DNA. Blots were exposed to X-ray films (Kodak) for three to five $d$.

\section{Statistical analysis}

$\mathrm{X}^{2}$ tests were used. Statistical significance was defined by $\mathrm{P}<0.05$.

\section{RESULTS}

\section{Morphological changes induced by ATRA consistent with apoptosis}

The effects of ATRA on the morphology of Ana-1 cells were tested using the fluorescent staining of nuclear DNA with PI. Treatment of Ana-1 cells with $10 \mu M$

(a)

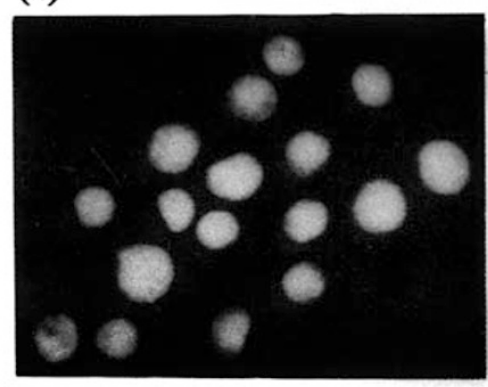

(b)

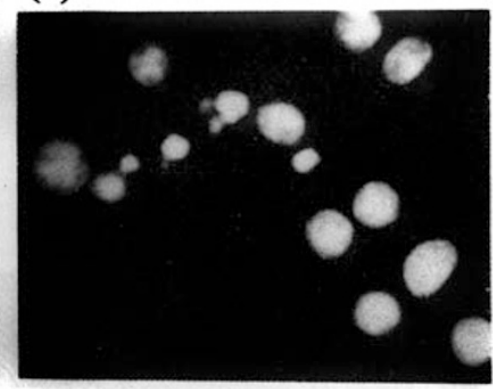

Fig 1. Effects of ATRA on the morphology of Ana-1 cells. Cultured cells were treated for $48 \mathrm{~h}$ with $10 \mu \mathrm{M}$ ATRA or control medium, fixed with methanol : acetic acid (3:1), and stained for 15 min with PI (30 $\mu \mathrm{g} / \mathrm{ml}$ in PBS). The slides loaded with the cells were washed, mounted in PBS, and observed under fluorescence microscope. Representative pictures are shown in (a) for control cells and in (b) for $10 \mu \mathrm{M}$ ATRAtreated cells $(48 \mathrm{~h})$. The control cells show intact nuclei but the ATRAtreated cells demonstrate signs of apoptosis, with condensation of nuclear masses at the nuclear membrane and nuclear fragmentation. 
ATRA-induced apoptosis and change of bcl-2 in Ana-1 cells

ATRA for 48 h (Fig 1) resulted in morphological changes characteristic of apoptosis, including condensation of chromatin at the nuclear membrane and nuclear fragmentation with groups of isolated pieces of condensed chromatin. Similar morphology of apoptosis was observed for the cells treated with $1 \mu M$ ACTD (data not shown).

\section{Time- and dose-dependent manners of ATRA-induced apoptosis}

Quantitation of apoptosis was determined in Ana-1 cells by counting at least 500 cells, and apoptotic cells are expressed in Fig 2 as percent of total Ana-1 cells counted with the mean \pm SEM. Counting cells at different intervals showed that no enhancement of apoptosis was detected at $12 \mathrm{~h}$ (data not shown) but significant apoptosis $(\mathrm{P}<0.01)$ could be observed at $24 \mathrm{~h}$ and reached the maximal level after $48 \mathrm{~h}$ of incubation with $10 \mu M$ ATRA, similar to that with $1 \mu M$ ACTD. ATRA at $1 \mu M$ was less effective in inducing apoptosis (Fig 2) and ATRA at $100 \mathrm{n} M \operatorname{did}$ not prompt apoptosis in Ana-1 cells (data not shown).

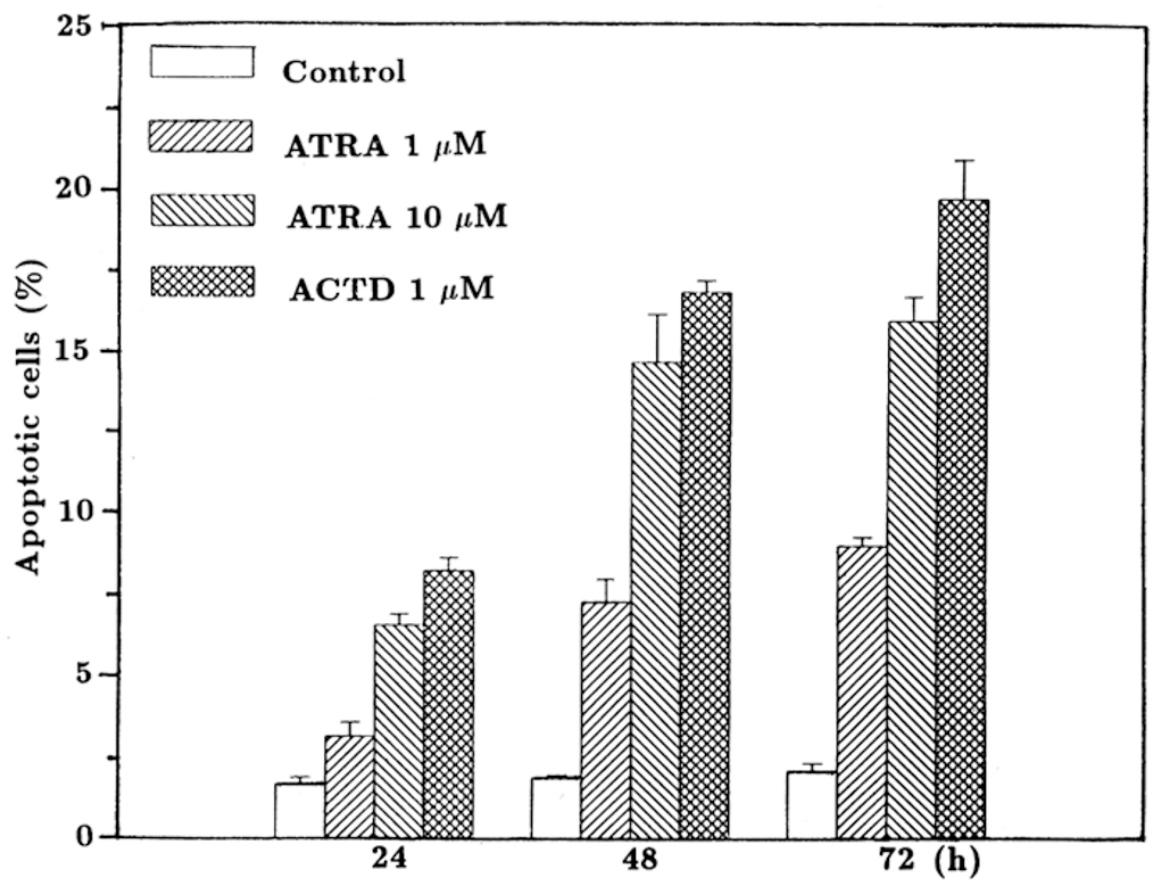

Fig 2. The percentage of apoptotic Ana-1 cells after ATRA treatment. Ana-1 cells were treated with indicated concentrations of ATRA or ACTD. Chromatin staining of the nucleus was performed by incubation with $30 \mu \mathrm{g} / \mathrm{ml}$ PI in PBS for $15 \mathrm{~min}$. Percentage of apoptotic cells was determined by counting at least 500 cells. Three independent experiments were carried out for at least three times, and the data were given as the mean \pm SEM. $\mathrm{X}^{2}$ analysis showed that the drug-induced apoptotic cells were significant higher than that in the control $(\mathrm{P}<0.01)$. 
Yin DL et al.

\section{Flow cytometry analysis of ATRA-induced apoptosis}

Flow cytometry was applied to further analyze apoptosis induced by ATRA in Ana-1 cells. After $48 \mathrm{~h}$ of incubation of the cells with ATRA, the apoptotic cells, as represented by the sub- $\mathrm{G}_{1}$ peak in the sample histograms (Fig 3), reached about $7 \%$ of the total cells for $1 \mu M$ and about $15 \%$ for $10 \mu M$ ATRA. ACTD ( $1 \mu M$ ), under the same conditions, induced about $17 \%$ of the cells to apoptosis. The apoptotic cells in the control were less than $2 \%$. The results, along with those after 24 or $72 \mathrm{~h}$ of ATRA treatment (data not shown), quantitatively agree with those obtained from the counting in Fig 2.

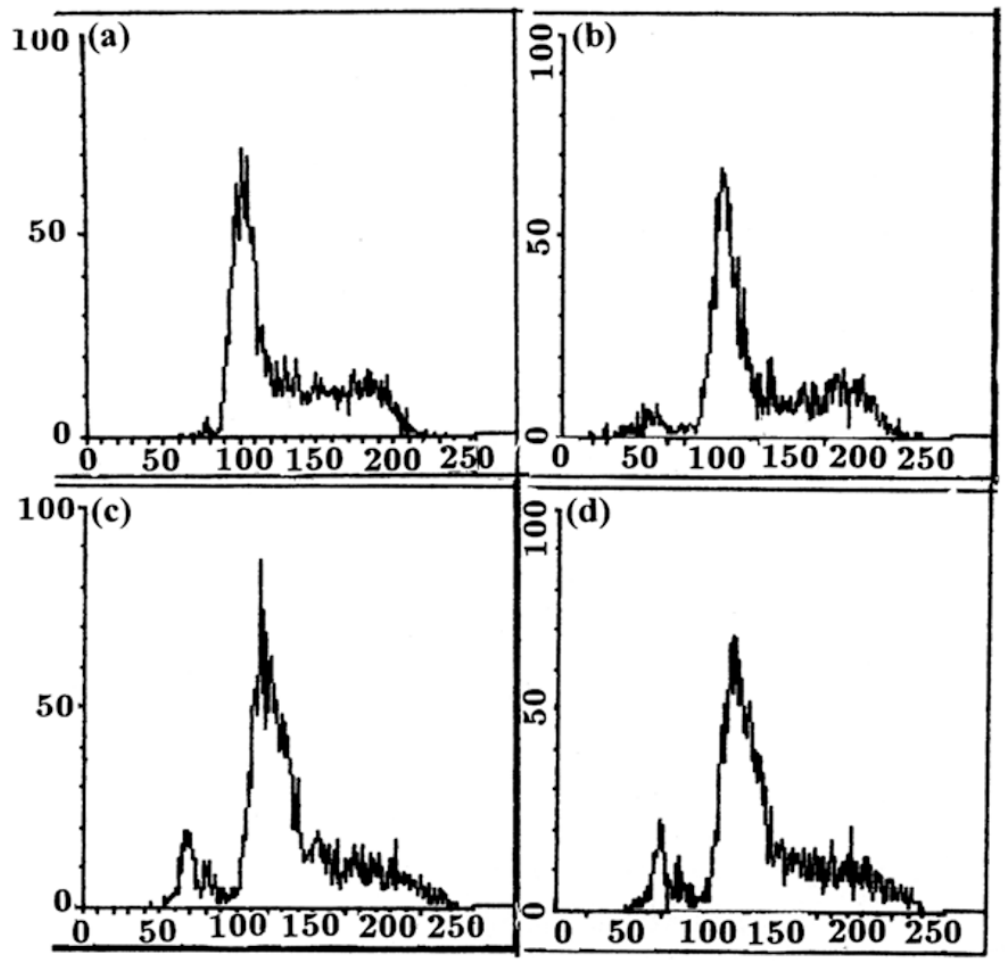

Fig 3. Fluorescence histograms of Ana-1 cells after treated with ATRA or ACTD for $48 \mathrm{~h}$. Representative histograms of DNA analysis by flow cytometry $(\mathrm{n}=3)$ were shown as indicated for control cells (a), $1 \mu M$ ATRA-treated cells (b), $10 \mu M$ ATRA-treated cells (c), and $1 \mu M$ ACTD-treated cells (d). $\mathrm{X}^{2}$ analysis showed the drug-induced apoptosis as measured by the area under sub-G1 peak in the histograms were significant higher than that in the control $(\mathrm{P}<0.01$ for $1 \mu M$ ATRA, $\mathrm{P}<0.001$ for $10 \mu M$ ATRA or $1 \mu M$ ACTD). X-axis represents fluorescence intensity and $\mathrm{Y}$-axis stands for relative cell numbers. 


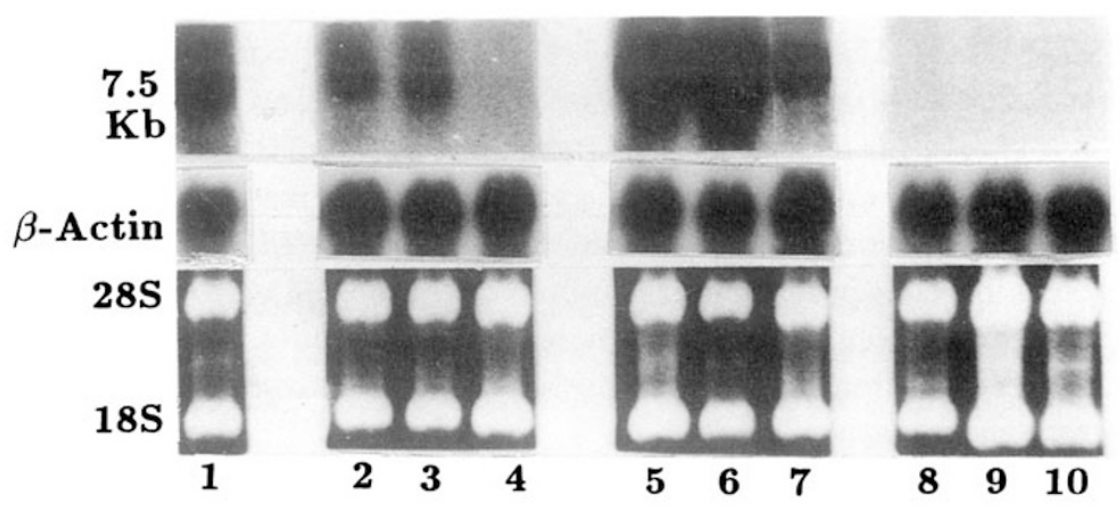

Fig 4. ATRA-induced changes of the mRNA levels of apoptosis-associated gene bcl-2 in Ana-1 cells. Northern blot analysis was carried out as described in "Materials and Methods". Bcl-2 gene is expressed in untreated Ana-1 cells (1). mRNA levels of

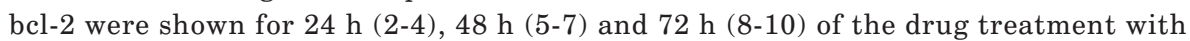
$1 \mu M$ ATRA $(2,5,8)$, with $10 \mu M$ ATRA $(3,6,9)$, or $1 \mu M \operatorname{ACTD}(4,7,10)$. Two independent experiments gave similar results.

ATRA-induced Changes of the mRNA levels of apoptosis-associated gene bcl-2

Expression of apoptosis-associated gene bcl-2 was detected by Northern blot analysis in drug-untreated Ana-1 cells as shown in Fig 4. After $24 \mathrm{~h}$ of ATRA treatment of the cells at both 1 and $10 \mu M$, the bcl-2 expression decreased. The mRNA levels of bcl-2 gene were higher than that of the control after $48 \mathrm{~h}$ but then almost totally diminished after $72 \mathrm{~h}$ of ATRA incubation. The temporal pattern of changes of bcl-2 mRNA levels after ATRA treatment was resembling to that after ACTD treatment. Two independent experiments gave similar results.

\section{DISCUSSION}

It has been known that retinoids can induce cell differentiation, which has been considered as one of the molecular mechanisms underlying the use of retinoids in cancer therapy[2]. A recent report has shown that retinoids promote apoptosis in human B lymphocyte cells[5], we designed to study if retinoids could induce apoptosis of macrophage cells.

The most direct method of detecting and quantifying apoptosis in cell cultures is to examine the morphology of cells after stained with fluorescent dyes such as PI[20]. A flow cytometry method based on a reduction in DNA staining and cell shrinkage has been also widely used for detection of apoptosis[21]. Both methods have been used in this study to detect apoptotic effect of ATRA in macrophage Ana-1 cells, and the results from both methods agreed well with each other.

With typical characteristics of apoptosis in Ana-1 cells after ATRA treatment as shown in Fig 1, combination of Fig 2 and 3 further confirmed that ATRA indeed 
prompts apoptosis in macrophage cells. Our results also indicated the time- and dose-dependent manners of the ATRA's action. Generally, it requires about $1 \mu M$ ATRA and more than $12 \mathrm{~h}$ for the drug to induce apoptosis in Ana- 1 cells. The apparent pattern of the effect of ATRA on apoptosis was resembling to that of ACTD, though the molecular mechanisms for the apoptotic effects of those two reagents may be different.

It has been shown that a series of genes are involved in regulation of apoptosis, and bcl-2 is one of the most relevant among them[6, 9, 10, 12, 18, 22]. Our study revealed that stimulation of Ana-1 cells with the retinoid could change the mRNA levels of bcl-2 gene. However, ATRA-induced changes of bcl-2 expression are in a complicated way: after initial decreasing at $24 \mathrm{~h}$, the levels of bcl-2 mRNA increased at $48 \mathrm{~h}$ and then almost totally diminished at $72 \mathrm{~h}$ of ATRA treatment. The ACTD incubation gave the qualitatively similar pattern of changes of bcl-2 expression. The results were reproducible in two independent experiments. We don't have a reasonable explanation, at the moment, for this phenomenon. It could be speculated that several parallel pathways may be involved in the regulation of apoptosis in macrophage Ana-1 cells, as depicted in other types of cells[23-29], and the interactions of these apoptotic pathways result in the complicated pattern of bcl-2 expression. Our results, anyway, clearly show that retinoid can induce the changes of bcl-2 expression. It remains to further examine if retinoids could induce the regulations of other apoptosis-related genes such as p53 in macrophage cells.

\section{ACKNOWLEDGMENTS}

This study was supported by research grants from Chinese Academy of Sciences and German Max-Planck Society. The authors thank professor Z. L. Zhang for supplying Ana-1 cell line, and professor Y. X. Zhang and Y. P. Wang for skillful technical assistance.

\section{REFERENCES}

[1] Morris-Kay G. Retinoids in Normal Development and Teratogenesis. Oxford University Press, New York. 1992.

[2] Smith MA, Parkinson DR, Cheson BD, Friedman MA. Retinoids in cancer therapy. J Clin Oncol 1992; 10:839.

[3] Moon RC, Mehta RG, Detrisac CJ. Retinoids as chemopreventive agents for breast cancer. Cancer Detect Prev 1992; 16:73.

[4] Zhu J, Shi XG, Chu HY, Tong JH, Chert Z. Effect of retinoic acid isomers on proliferation, differentiation and PML relocalization in the APL cell line NB4. Leukemia 1992; 9:302.

[5] Jennifer MT, Satoshi F, Francis WR, Maria CBR. Growth inhibition and apoptosis of RL human B lymphoma cells by vitamine $\mathrm{E}$ succinate and retinoic acid: role for transforming growth factor. Cell Growth and Diff 1995; 6:655.

[6] Domenico D, Antonella A, Franca F, Enrico F, Marco AP. Regulation of apoptosis induced by the retinoid N-(4-hydroxypheny I) retinamide and effect of deregulated bcl-2. Blood 1995; 85:359. 


\section{ATRA-induced apoptosis and change of bcl-2 in Ana-1 cells}

[7] Chen ZX, Xue YQ, Zang R, Xia XM, Zu WY. A clinical and experiment study on all-trans retinoic acid-treated acute promyelocytic leukemia patients. Blood 1991; 78:1413.

[8] Zheng L, Fisher G, Miller RE, Peschon J, Lenardo MJ. Induction of apoptosis in mature T cells by tumour necrosis factor. Nature 1995; 377:348.

[9] Lotem J, Sachs L. Control of sensitivity to induction of apoptosis myeloid leukemic cells by differentiation and bcl-2 dependent and independent pathways. Cell Growth and Diff 1994; 5:321.

[10] Deborah JV, Sorenson CM, Shutter JR, Korsmeyer SJ. Bcl-2-deficient mice demonstrate fulminant lymphoid apoptosis, polycyst kidneys, and hypopigmented hair. Cell 1993; 75:229.

[11] Earnshaw WC. Apoptosis: lessons from in vitro systems. Trends in Cell Biol 1995; 5:217.

[12] Hockenbery DM, Oltvai ZN, Korsmeyer SJ. Bcl-2 function in an antioxidant pathway to prevent apoptosis. Cell 1993; 75:241.

[13] Lotem J, Sachs L. Regulation by bcl-2, c-myc and P53 of susceptibility to induction of apoptosis by heat shock and cancer chemotherapy compounds in differentiation competent and defective myeloid leukemic cells. Cell Growth and Diff 1993; 4:41.

[14] Lotem J, Cragoe EJ, Sachs L. Rescue from programmed cell death in leukemic and normal myeloid cells. Blood 1991; 78:953.

[15] Yonish-Rouach E, Resnitzky D, Lotem J, Sachs L, Kimchi A, Oren M. Wild-type P53 induces apoptosis of myeloid leukemic cells that is inhibited by interleukin 6 . Nature 1991; 352:345.

[16] Turley JM, Sanders BG, Kline K. RAR tocopheryl succinate modulation of human promyelocytic leukemia (HL-60) cell proliferation and differentiation. Nutrition and Cancer 1992; 18:201.

[17] Dive C, Cregory CD, Phipps DJ, Evens DL, Milner AE, Wyllie AH. Analysis and discrimination of necrosis and apoptosis by multiparameter flow cytometry. Biochem Biophys Acta 1992; 1133:275.

[18] Delia D, Aiello A, Soligo D, Fontanella E, Melanic Pezzella F, Pierotti MA, Della PG. Bcl-2 proto-oncogene expression in normal and neoplastic human myeloid cells. Blood 1992; 79:1291.

[19] Cleary ML, Sklar J. Nucleotide sequence of at $(14 ; 18)$ chromosomal breakpoint in follicular lymphoma and demonstration of a breakpoint cluster region near a transcriptionally active locus on chromosome 18. Proc Natl Acad Sci USA 1985; 82:7449.

[20] Martin S, Bradley J, Cotter T. HL-60 cells induced to differentiate towards neutrophils subsequently die via apoptosis. Clin Exp Immunol 1990; 79:448.

[21] Telford WG, King LE, Fraker PG. Rapid quantitation of apoptosis in pure and heterogeneous cell populations using flow cytometry. Journal of Immunol. Methods 1994; 172, 1.

[22] Nunez G, Clsarke MF.The bcl-2 family of proteins: regulators of cell death and survival. Trends in Cell Biol 1994; 4:399.

[23] Busciglio J, Yankner BA. Apoptosis and increased generation of reactive oxygen specise in Down's syndrome neurons in vitro. Nature 1995; 378:21.

[24] Graeber TG, Osmanian C, Jacks T, Housman DE, Lowe SW, Giaccia AJ. Hypoxia-mediated selection of cells with diminished apoptotic potential in solid tumours. Nature 1996; 379:88.

[25] Cohen JJ. Exponential growth in apoptosis. Immunol Today 1995; 16:346.

[26] Liston P, Roy N, Tamal K, Lefebvre C, Korneluk RG. Suppression of apoptosis in mammalian cells by NAIP and a related family of IAP genes. Nature 1996; 379:349.

[27] Verheij M, Bose R, Lin XH, Yao B, Fuks Z, Kolesnick RN. Requirement for ceramide-initiated SAPK / JNK signalling in stress-induced apoptosis. Nature 1996; 380:75.

[28] Osborne BA, Lawrence M. Essential genes that regulate apoptosis. Trends in Cell Biol 1994; 4:394.

[29] White K, Steller H. The control of apoptosis in Drosophila. Trends in cell Biol 1995; 5:74.

Received 24-10-1996. Revised 27-11-1996. Accepted 30-11-1996. 